\title{
Livin Expression by Semi-quantitative Immuno-flourecent Staining in Hodgkin Lymphoma: A Promising Marker or a Leading Role in Pathogenesis?

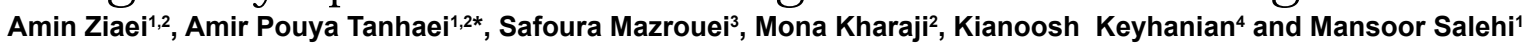

${ }^{1}$ Medical School, Isfahan University of Medical Sciences, Genetics and Molecular Biology, Isfahan, Iran

${ }^{2}$ Medical School, Isfahan University of Medical Science, Medical Student Research Center, Isfahan, Iran

${ }^{3}$ Faculty of Medicine, Friedrich Schiller, University of Jena, Jena, Germany

${ }^{4}$ Ottawa Hospital Research Institute, Ontario, Canada

\begin{abstract}
A novel human inhibitor of apoptosis protein family member, termed Livin, was demonstrated in the pathogenesis of different human malignancies, and also it was studied as a potential treatment target in malignancies. However, there is no report on the Livin expression profile in Hodgkin Lymphoma. In this study, we evaluated the Livin expression in 78 paraffin embedded blocks including 39 staged cases of Hodgkin Lymphoma and 39 control subjects (normal and reactive hyperplasia lymph nodes). Tissue Microarray-based Semi-quantitative Immuno-flourecent Staining was applied for protein expression profiling in both infiltrating non-neoplastic cells (morphologically typical Lymphocytes) and neoplastic cells (Hodgkin and Reed-Sternberg) of cases and control samples. Our results demonstrated that the mean ratio of Livin/GAPDH expression was significantly increased between infiltrating background cells in Hodgkin Lymphomas and control cases $(0.54596$ vs. $0.50827, \mathrm{P}<0.001)$. Also, a significant difference was found in the mean ratio of Livin/GAPDH expression between neoplastic cells and major background cells in the tumor microenvironment $(0.59024$ vs. $0.54596, p<0.001)$. Furthermore, this study confirmed a significant increase of Livin expression from early-stage to advanced-stage of Hodgkin Lymphoma $(0.52888$ vs. $0.580146, \mathrm{P}<0.01)$. These findings suggest that Livin may play a critical role in the pathogenesis of Hodgkin Lymphoma. It also can be a novel prognostic marker and a potential therapeutic target in this type of lymphoma.
\end{abstract}

Keywords: Hodgkin lymphoma; Reed-Sternberg cell; Inhibitor of Apoptosis Protein; Livin/BIRC 7; Semi- quantitative Immunoflourecent Staining

\section{Introduction}

Hodgkin Lymphoma (HL) is the most striking example of tight tumor-host relationship [1]. About $95 \%$ of HL belongs to the classical form of the disease [2] and based on the frequencies of cellular components and histo-pathological features, it is sub-typed to four entities: NodularSclerosis Classic Hodgkin Lymphoma (NSCHL), Mixed Cellularity Classic Hodgkin Lymphoma (MCCHL), Lymphocyte- Rich Classic Hodgkin Lymphoma (LRCHL), lymphocyte Depleted Classic Hodgkin Lymphoma (LDCHL) [3], while the remaining 5\% represent Nodular Lymphocyte Predominant Hodgkin Lymphoma (NLPHL) $[2,3]$. This lymphoma is characterized by heterogeneous cellularity, including a majority of reactive and inflammatory non-neoplastic cells and a minority of specific neoplastic cells -the multinucleated Reed Stern-berg and its mono-nucleated variants, Hodgkin and ReedSternberg (HRS) cells. Unlike most other cancers, malignant cells in $\mathrm{HL}$ are outnumbered by background cells in the microenvironment of tumor $[4,5]$, which accounts for only about $1 \%$ of all cells in the tumor tissue $[1,2,4]$. In addition, as for HL, major reactive cells in lymph node are lymphocytes (mostly T-cell) [6], macrophages/histiocytes, eosinophils, mast cells, plasma cells, fibroblast and neutrophils [6-9].

Growing attention has been focused on understanding the exact pathological aspect of HL so far, but its molecular biology is still poorly understood [5]. Although HL in general has a favorable prognosis but more molecular studies are required for the refractory and relapsed patients [9-12] to discover the unresolved molecular pathobiological issues of HL $[2,13,14]$. Recently, advances in molecular profiling of HRS cells have shown that this small number of malignant cells have a potential role in the HL pathogenesis through different pathways like providing a typical microenvironment by secretion of cytokines and chemokines (CCL5, CCL17, CCL22, IL5, TGF- $\beta$, PDGF, IL2, IL6
$[2,4,15]$, deregulating of transcription factor network [2], and escaping from apoptosis $[13,15,16]$.

The numerous literature has been reported on the critical role of apoptosis in different pathological conditions like neurodegenerative disorders [17] and cancers, and particularly hematolymphoidneoplasias [16,18-22]. Interestingly, this is a solid notion that defective apoptosis rather than increased cell proliferation is the primary cause of malignant lymphopoiesis [21]. So, the impaired regulation of apoptosis is considered to be a prominent event in the development and progression of hematological malignancies [20,21]. The mechanisms of these defects, however, have not been fully elucidated. But Bcl2 and Inhibitor of apoptosis protein (IAP) gene families, which have been known as hallmarks of apoptosis regulation [20], are considered as the main culprits in the pathogenesis of these malignancies [18,23-27]. So far, as many as eight human IAP members have been identified, NAIP/ BIRC1, cIAP-1/BIRC2, cIAP-2/BIRC3, XIAP/BIRC4, SURVIVIN/ BIRC5, BRUCE/BIRC6, ILP-2/BIRC8 and our subjected novel one in this study, Livin/ML-IAP/BIRC7 [27,28].

Livin is a $39 \mathrm{kDa}$ protein consisting of a single BIR domain and a RING finger motif. Structurally, Livin-BIR forms a globular

*Corresponding author: Amir Pouya Tanhaei, Medical School, Isfahan University of Medical Science, Medical Student Research Center, Isfahan, Iran, Tel: +98-311-6244828; Fax: +98-311-6688597; E-mail: a_p_t80@yahoo.com

Received November 07, 2014; Accepted December 26, 2014; Published December 28, 2014

Citation: Ziaei A, Tanhaei AP, Mazrouei S, Kharaji M, Keyhanian K et al. (2015) Livin Expression by Semi-quantitative Immuno-flourecent Staining in Hodgkin Lymphoma: A Promising Marker or a Leading Role in Pathogenesis?. J Cytol Histo 6: 299. doi:10.4172/2157-7099.1000299

Copyright: (C) 2015 Ziaei A, et al. This is an open-access article distributed unde the terms of the Creative Commons Attribution License, which permits unrestricted use, distribution, and reproduction in any medium, provided the original author and source are credited. 
conformation conserved by four $\alpha$-helices and a three-stranded antiparallel $\beta$-sheets $[29,30]$. The Livin gene has two splice variants, Livin $\alpha$ and Livin $\beta$, which are almost identical but with different tissue and cellular distributions [31,32]. Livin plays a critical role in apoptosis inhibition [33]. It has been reported that Livin directly interacts with executioner Caspase- 3 and-7 in vitro and initiator Caspase-9 in vivo through its BIR domain [34]. BIR domain has a vital role in IAP function, and mutations in the BIR domain reduce both inhibition of Caspase- 9 and general anti-apoptotic capacity of the cells $[29,35,36]$. In addition to apoptosis inhibition, Livin is also involved in the regulation of cell proliferation by arresting cell cycle at G0/G1 phase [32,37]. Regarding Livin function in human cells, numerous studies have reported that Livin up-regulation is a risk factor for cancer progression and unfavorable prognosis [38]. There are evidences showing that Livin expression significantly increases in series of cancers [39] including colon cancer [40], bladder cancer [32,41], lung cancer [26,32], neuroblastoma [17,42], pancreatic cancer [43], osteosarcoma, renal cell carcinoma [34], leukemia [38], and of course non-hodgkin lymphoma $[16,32,44]$

So far, there is no report regarding the Livin expression in $\mathrm{HL}$, especially the Livin role in the deregulation of apoptosis in the reprogrammed-HRS cells and also no study has discussed the prognostic significance of Livin in HL as a promising and informative biomarker. In order to find possible differences in Livin expression in both malignant and non-neoplastic cells, we examined the Livin expression in 39 staged cases of HL and the same number of control samples using semi-quantitative immunofluorescent staining on Formalin-Fixed Paraffin-Embedded (FFPE) sections. Besides, we evaluated the Livin expression in early-stage cases (clinical stages of I and II) and advanced-stage ones (clinical stages of III and IV based on Ann Arbor staging classification for HL) [45,46], and Livin expression among different histologic subtypes of HL.

\section{Materials and Methods}

\section{Patient and donor material}

In this study, Livin expression was examined in 78 paraffin embeds blocks including 39 HL FFPE-tissue blocks and 30 and 9 FFPE-tissue blocks with diagnosed normal and reactive hyperplasia lymph nodes, respectively.

The lymph nodes were excised in the department of surgery, University Hospital of SeyedAlshohada and Al'zahra, Isfahan University of Medical Sciences, from 2006 to 2010.

Primary diagnosis of CHL was made based on histological examination through $\mathrm{H} \& \mathrm{E}$ staining and confirmed morphology diagnosis of RS cells by expert panel and also based on immunohistochemical examination we accepted RS cells (in order to consider as CHL cases) which is express CD15 (85 percent of cases) and CD30 (all cases except case of NLPHL), and lack global expression of pan-B (CD19, CD20, CD79a) and pan-T (CD3, CD7) antigens. Finally, eligible lymph node blocks for this study were confirmed again by hematopathologist with supplementary immunohistochemical staining (Data not shown). The histological examination included 39 HL lymph node blocks, and also, 18, 14, 4, 2 and 1 of NSCHL, MCCHL, LRCHL, LDCHL, and NLPHL respectively.

Clinical features of all patients including sex, age, B-symptom (fever, night sweats, weight loss), lymph node involvement site (cervical, auxiliary, mediastinum, paraaortic, perihilar, inguinal) and extra-lymphatic organ involvement (lung, liver, spleen, bone marrow) were recorded and clinical staging based on Ann Arbor criteria was performed by an oncologist. Among 39-HL patients, 10, 9, 4 and 8 were diagnosed to be at stages of I, II, III and IV, respectively. Besides, in this study, we determined another staging style, which assumed stage I and II as early-stages and stage III and IV as advanced-stages [45,46]. Some limited cases did not have the required clinical information for staging, so they were considered in an undefined stage group. Informed consent was taken for all donor materials.

\section{Immunostaining}

The samples were subjected to paraffin wax histology using a standard method. Histological sections $(3 \mu \mathrm{m})$ were cut using a Jung rotary microtome, floated out on a 50-50 volume mixture of absolute ethanol-distilled water at $48^{\circ} \mathrm{C}$, and then mounted on glass microscope slides, which were previously coated with 3 -aminopropyltriethoxysilane prior to overnight storage at $37^{\circ} \mathrm{C}$.

The semi-quantitative method used in this study was the same method developed and applied in our previous studies [47-49]. We used two antibodies against Livin and GAPDH. Livin and GAPDH protein expression were measured using semi-quantitative immunofluorescent assay. For Livin detection, we used Livin primary antibody of Baculoviral IAP Repeat -containing (BIRC7/Livin) Rabbit anti-Human, IgG polyclonal antibody (Life Span Bio Siences, Lot ID:LS-B456/10844) GAPDH primary antibody was Glyceraldehyde 3-Phosphate Dehydrogenase (GAPDH) mouse anti-Human, IgG monoclonal (2D4A7) antibody (Life Span Bio Siences, Lot ID:LS-B520). Fluorochrome-conjugated secondary antibody against the species of the anti-livin and anti-GAPDH antibodies were Fluorescein (FITC) Affini Pure Goat anti-rabbit,IgG $(\mathrm{H}+\mathrm{L})$ and Texas Red Affini Pure Goat anti- mouse, IgG $(\mathrm{H}+\mathrm{L})$ respectively. These reagents were purchased from Jackson Immuno Research Laboratories (West Grove, PA, USA).

Slide preparation involved transferring sections to slides, removal of paraffin, re-hydration and also antigen retrieval treatment. As antigen retrieval treatment we used R\&D Systems protocol to promote epitope availability and enhance immunoreactivity. Antigen Retrieval Reagent-Basic is an antigen retrieval system that utilizes heat-induced recovery of cell and tissue antigens. (Catalog NO. CTS013) Sections were de-paraffinized through Microwave oven $\left(67^{\circ} \mathrm{C}\right.$ for $\left.45 \mathrm{~min}\right)$ and Xylene treatment $(4 \times 10 \mathrm{~min})$. Then, they were gradually rehydrated in the following order: Abselout Alcohol $(1 \times 5 \mathrm{~min}), 95 \%$ Alcohol $(1 \times 5$ $\mathrm{min}), 85 \%$ Alcohol $(1 \times 5 \mathrm{~min})$ and finally $75 \%$ Alcohol $(2 \times 5 \mathrm{~min})$, deionised water ( $5 \mathrm{~min})$, Phosphate buffer saline (PBS) $(2 \times 5 \mathrm{~min})$. After re-hydration, slides were allowed to dry at room temperature, and then with DAKO Pen, the rim of tissue section on the slides was marked. Next, $150 \mu \mathrm{l}$ of PBS was added to each slide and it was incubated for 15 minutes at $37^{\circ} \mathrm{C}$ in a humidified chamber before antibody treatment. Primary antibodies (Livin and GAPDH) were diluted to its optimal dilution (1/100) in diluents. After that, $50 \mu \mathrm{l}$ of the primary antibodies were added to the slides and they were incubated for 45 minutes at $37^{\circ} \mathrm{C}$ before rinsing slides with PBS. The following steps need to be done in darkness.

The secondary conjugated antibodies were diluted to its optimal dilution $(1 / 50)$ in diluents. Then, $50 \mu$ lof secondary antibody was applied to each slide, the slides were then incubated for 1 hour at $37^{\circ} \mathrm{C}$, before washing in PBS $(2 \times 10 \mathrm{~min})$. In this study, Livin was stained with FITC and GAPDH was stained with Texas Red conjugation. Finally, all slides covered with a cover slip, sealed with clear nail polish and kept in a cold and dark place. 
Citation: Ziaei A, Tanhaei AP, Mazrouei S, Kharaji M, Keyhanian K et al. (2015) Livin Expression by Semi-quantitative Immuno-flourecent Staining in Hodgkin Lymphoma: A Promising Marker or a Leading Role in Pathogenesis?. J Cytol Histol 6: 299. doi:10.4172/2157-7099.1000299

\section{Image analysis}

Prepared slides were examined using a LEICA fluorescence microscope (BZ00) with filter sets suitable for FITC \& Texas Red dyes. Two images were taken from each microscope field, one with blue filter $(350-450 \mathrm{~nm})$ and the other with green filter $(550-650 \mathrm{~nm})$.

Furthermore, 20 to 30 images were taken for each sample from different sites of the tissue section, randomly. Images were captured using a cooled charge coupled device (CCD) camera (LEICA: DC 350F) interfaced with a PC computer. We analyzed these saved images using image-processing algorithms in MATLAB.7 software (http:// www.mathworks.com). The whole boundary of desired cells in both green and red planes of our available images was selected and then the ratio of intensity between the mean of pixels in the green and red plane of selected cells was computed by following ratio formula:

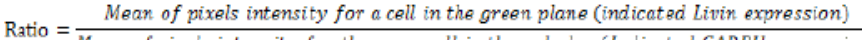

Mean of pixe's intensity for the same cell in the red plae (Indicated GADPH expression)

Unlike some previous studies, which selected and analyzed images randomly among all samples $[17,48]$, samples were analyzed one to one in this study in order to acquire highly accurate and trustworthy results. Of all taken images for each sample, a 30-cell- collection was selected and then analyzed by MATLAB 7 . The total cell count was around 2060 cells in all prepared HL and control sections.

We could not completely eliminate autofluorescence, so we excluded autoflurescence artifacts from the evaluation by selecting appropriate cells. The desired cells for analyzing were morphologically typical lymphocytes. Although the selection of HRS cells in immunofluorescence stained samples may be challenged by using conventional immunofluorescence as morphological details, we selected about 20 morphologically definite typical neoplastic HRS cells in HL samples and also confirmed it by two Hematopathologists independently.

\section{Statictical analysis}

One-way analysis of variance (ANOVA) and student's t-test were run to analyze the mean level of Livin expression ratio between case and control groups and their subdivides. Furthermore, $\chi^{2}$ and Fisher's exact tests were applied to analyze data in clinical features of this study (Table 1).

\section{Results}

In this study, the expression of Livin in 39 staged HL was compared to 39 non-neoplastic lymphoid tissues (30 normal and 9 reactive hyperplasia lymph nodes). Livin protein expression was measured in all samples. To fulfill this purpose, multi-color FISH method was modified and applied for semi-quantitative Immuno-flourecent method [47]. This procedure had been developed to detect expression of more than one protein within the same cell, at the same time $[48,49]$. In fact, the quantitative evaluation of any subjected protein expression would be achieved only by considering the relative hybridization signal intensities from two different proteins: One with a variable expression and another with a constant expression termed housekeeping gene in neoplastic and normal lymphoid tissue. We calculated alteration in the expression of Livin protein in our samples based on the decrease or increase in Livin/GAPDH ratio. Any change in the ratio of green (conjugated hybrid with Livin) to red (conjugated hybrid with GAPDH) indicates variation of the expression of Livin (Figure 1).

To determine whether or not Livin up-regulation occurs in neoplastic tissue, 1030 infiltrating cells were analyzed in the tumor environment (morphologically typical lymphocytes) and approximately the same number of background cells in normal and reactive environment of lymph node was considered. Mean Ratio (M.R) of Livin/GAPDH expression in all HL cases was $0.5459 \pm 0.0612$ and in the control group, it was $0.50 \pm 0.0267$. So, Livin expression was significantly higher in HL than normal and reactive samples $(\mathrm{P}<0.001$, t-test) (Figure 2).

Surprisingly, there was no statistical difference between the Livin expression in normal (M.R of Livin/GAPDH expression $=0.5085 \pm$ 0.0284 ) and reactive hyperplastic lymph nodes (M.R of Livin/GAPDH expression $=0.5068 \pm 0.0213)(\mathrm{p}>0.05)$ (Figure 3$)$.

Furthermore, all diagnosed malignant cells (HRS) in the HL (Figure 1) were analyzed for Livin expression (M.R of Livin /GAPDH expression $=0.5902 \pm 0.0135)$ and compared with all infiltrating cells (M.R of Livin $/$ GAPDH expression $=0.5459 \pm 0.06126)$ in HL, $(\mathrm{P}<0.001$, paired t-test) (Figure 4). The expression of Livin in malignant cells was significantly higher than reactive inflammatory cells either, $(\mathrm{P}<0.001$, paired t-test) (Figure 4).

Based on Ann Arbor classification, we examined Livin expression in 32 patients with definite staged HL. Of the total of 32 cases, 19 and 13 were at early-stage (I and II) and advanced-stage (III and IV), respectively. In the first group, the M.R of Livin /GAPDH expression was $0.5288 \pm 0.0418$ and for the second one, it was $0.5801 \pm 0.06941$. The differences between stages in HL were statistically significant $(\mathrm{P}<0.01$, t-test) (Figure 5).

Based on the varying proportion of neoplastic and non-neoplastic cells, of $39 \mathrm{HL}$ samples, 18, 14, 4, 2 and 1 cases were diagnosed with NHCHL, MCCHL, LRCHL, LDCHL and NLPHL histological patterns, respectively. There was no significant relevance between Livin expression in different entities of HL (Figure 6). Although the livin expression is the same for all histological types of Hodgkin lymphoma, it may be acceptable for NHCHL, MCCHL. However, there are a few number of the other types likeLRCHL, LDCHL and NLPHL.

The ROC curve reveals a cut-off point for Mean Ratio (M.R) of Livin/GAPDH expression at 0.5231 ,maximized true positives and also true negatives (sensitivity $74.9 \%$, specificity $74.4 \%$ ), distinguishing HL from non neoplastic lymph node samples as a control group in difficult cases with Area under the curve (AUC) of 0.761 (Figure 7 and Table 2).

The ROC curve revealed that the Mean Ratio (M.R) of Livin/ GAPDH expression could be an accurate marker in order to distinguish HL from non neoplastic lymph node samples as a control group. $($ AUC $=0.761, P$ value $<0.0001)$

\begin{tabular}{|c|c|c|c|c|c|c|c|}
\hline Medium age & \multicolumn{7}{|c|}{$33.8 \pm 15.2$} \\
\hline Sex & \multicolumn{4}{|c|}{ Male $=21$} & \multicolumn{3}{|c|}{ female $=18$} \\
\hline \multirow{2}{*}{$\begin{array}{c}\text { B symptom } \\
\text { 1-Fever } \\
\text { 2-nightsweat } \\
\text { 3-weight loss }\end{array}$} & \multicolumn{4}{|c|}{ Positive $=14$} & \multicolumn{3}{|c|}{ negative $=17$} \\
\hline & \multicolumn{7}{|c|}{$\begin{array}{l}9 \text { out of } 14 \\
7 \text { out of } 14 \\
8 \text { out of } 14\end{array}$} \\
\hline \multirow{3}{*}{$\begin{array}{l}\text { Lymph node } \\
\text { Involvement }\end{array}$} & \multicolumn{7}{|c|}{ Cervical /auxiliary/mediastinal/paraaortic/perihilar/ inguinal } \\
\hline & Yes & 26 & 5 & 9 & 3 & 3 & 4 \\
\hline & No & 5 & 25 & 22 & 29 & 28 & 28 \\
\hline $\begin{array}{c}\text { extra-lymphatic } \\
\text { organ } \\
\text { involvement }\end{array}$ & $\begin{array}{c}\text { Lung } \\
3\end{array}$ & \multicolumn{2}{|c|}{$\begin{array}{l}\text { liver } \\
2\end{array}$} & \multicolumn{2}{|c|}{$\begin{array}{c}\text { spleen } \\
3\end{array}$} & $\begin{array}{c}\text { bone marrow } \\
0\end{array}$ & $\begin{array}{c}\text { Others } \\
4\end{array}$ \\
\hline
\end{tabular}


Citation: Ziaei A, Tanhaei AP, Mazrouei S, Kharaji M, Keyhanian K et al. (2015) Livin Expression by Semi-quantitative Immuno-flourecent Staining in Hodgkin Lymphoma: A Promising Marker or a Leading Role in Pathogenesis?. J Cytol Histol 6: 299. doi:10.4172/2157-7099.1000299

Page 4 of 7

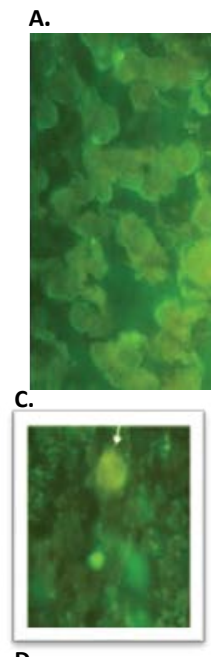

D.
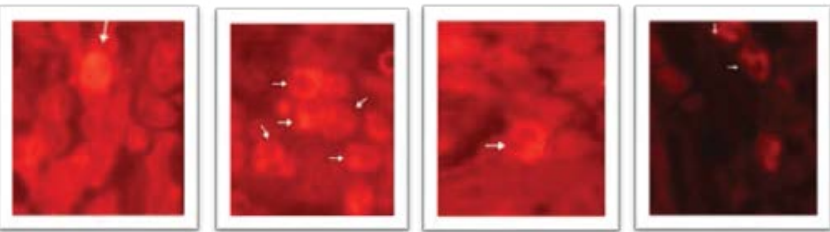

Figure 1: Representative LIVIN and GAPDH expression detected by FITC and Texas Red conjugated antibodies, respectively. (A) and (B) are images of infiltrating reactive cells in HL. Images (C) and (D) show some HRS cells in $\mathrm{HL}$.

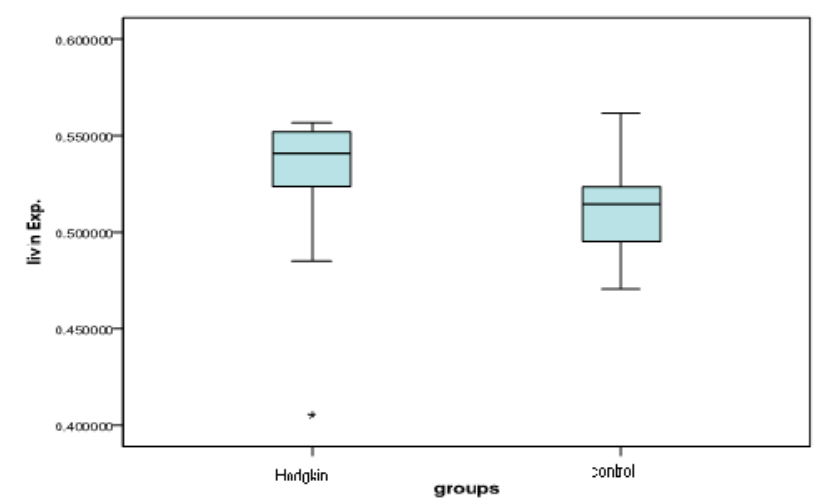

Figure 2: Livin/GAPDH expression in 39 cases of $\mathrm{HL}$ and 39 cases of control (normal and reactive) lymph nodes. The Livin protein expression in $\mathrm{HL}$ and control groups was statistically significant $(P<0.001)$.

Our study, moreover, revealed that probably there are no correlation between the level of the Livin expression and other factors like age, gender, B symptom and lymphoid and extra-lymphoid tissues involvements. Clinical features of case groups are shown in (Table 1).

\section{Discussion}

This study sheds new light on the prognostic significance of Livin expression previously described in human malignancies [21,39]. Livin was identified from malignant melanoma, and described as the melanoma IAP [28]. So far, it is reported that up-regulation and/or abnormal Livin expression has been detected during the process of cancer formation as well as progression [32] and also our reports show the critical role of Livin in HL. Numerous studies have validated that over expression of Livin is a potential prognostic and diagnostic biomarker [28]. While in some studies, this issue has not been confirmed. The prognosis importance of Livin has been shown in neuroblastoma, bladder cancer and NHL $[28,41,42,44]$. In 2005, Kim et al., have shown that the expression of Livin in neuroblastoma cells has a positive correlation with prognosis and outcome of the disease [42]. Also, Gazzaniga et al., in 2003, reported the role of over expression and prognostic significance of Livin in the progression of superficial bladder cancer, with median relapse-free time of Livin-positive patients being

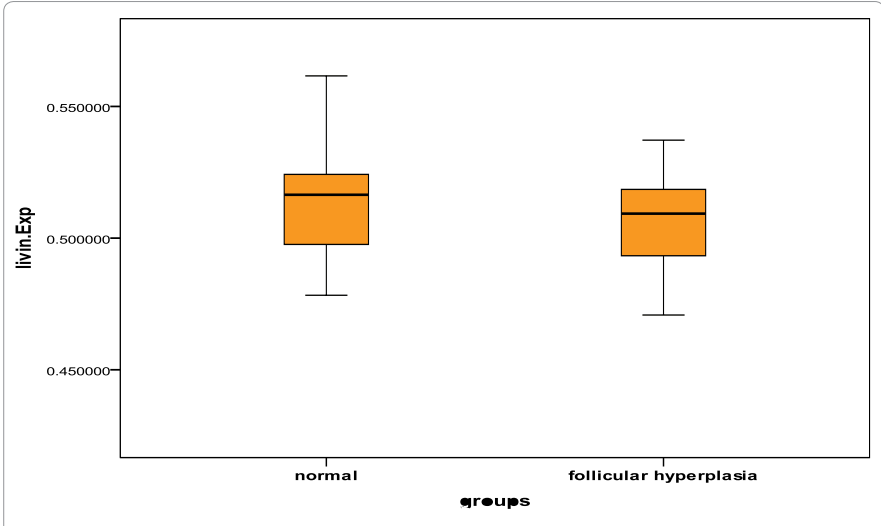

Figure 3: Livin/GAPDH expression in 30 normal and 9 reactive hyperplasia lymph nodes. The Livin protein expression between these groups was not statistically significant.

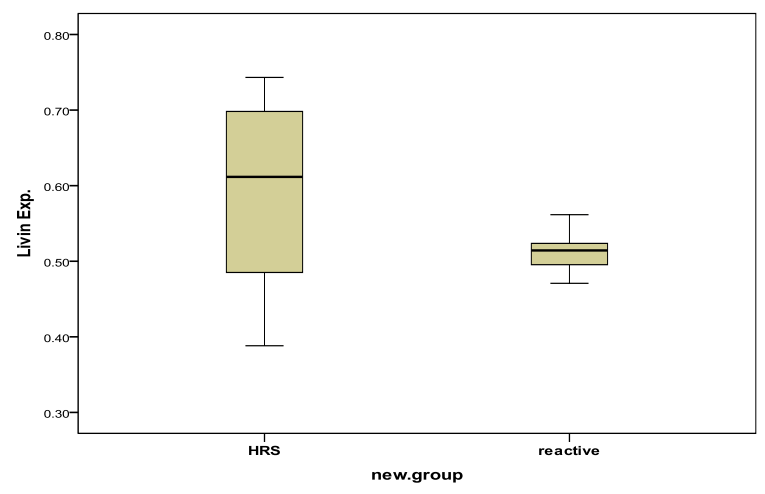

Figure 4: Livin/GAPDH expression in malignant (HRS) and non-malignant cells in HL. The Livin protein expression between these different populations was significant $(P<0.001)$.

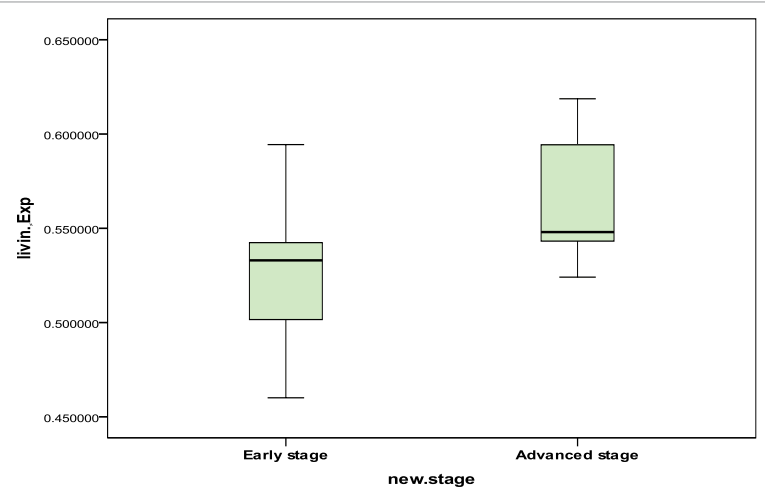

Figure 5: Livin/GAPDH expression between Early- stage and advancedstage in $\mathrm{HL}$. The change of Livin protein expression was statistically significant in different clinical stages in $\mathrm{HL}(\mathrm{P}<0.001)$. 
Citation: Ziaei A, Tanhaei AP, Mazrouei S, Kharaji M, Keyhanian K et al. (2015) Livin Expression by Semi-quantitative Immuno-flourecent Staining in Hodgkin Lymphoma: A Promising Marker or a Leading Role in Pathogenesis?. J Cytol Histol 6: 299. doi:10.4172/2157-7099.1000299

Page 5 of 7

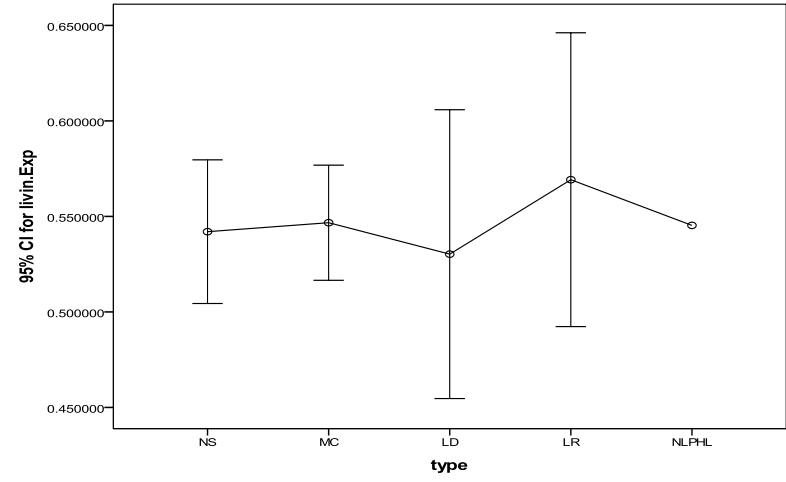

Figure 6: The M.R. of Livin/GAPDH expression among five histological entities of HL. No significant relevance is noticed between Livin expressions.

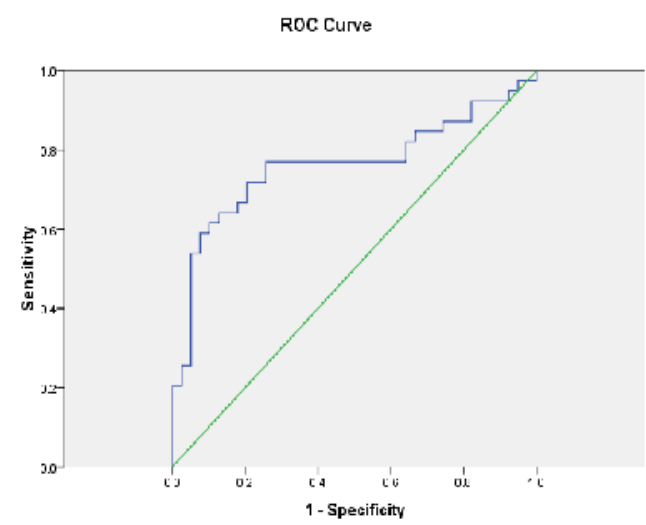

Figure 7: Diagnostic statistics = ROC curve of Livin/GAPDH expression for the discriminating $\mathrm{CHL}$ from non-neoplastic lymph node samples as control group $(A \cup C=0.761)$.

\begin{tabular}{|l|c|c|c|l|}
\hline & Points & Sensitivity\% & Specificity\% & AUC \\
\hline $\begin{array}{l}\text { Optimal } \\
\text { Cut-off point }\end{array}$ & 0.5231 & 74.9 & 74.1 & 0.761 (95\% Cl 0.648 to 0.874) \\
\hline $\begin{array}{l}\text { Cut-off point } \\
\text { with higher } \\
\text { sensitivity }\end{array}$ & 0.5032 & 82.1 & 35.9 & $0.761(95 \% \mathrm{Cl} 0.648$ to 0.874) \\
\hline $\begin{array}{l}\text { Cut-off point } \\
\text { with higher } \\
\text { specificity }\end{array}$ & 0.5334 & 61.5 & 89.7 & 0.761 (95\% Cl 0.648 to 0.874$)$ \\
\hline
\end{tabular}

AUC, areas under the curve; $95 \% \mathrm{Cl}, 95 \%$ confidence interval.

Table 2: The cut-off points to discriminate $\mathrm{HL}$ from non neoplastic lymph node according to MR of Livin/GAPDH expression.

obviously shorter than that of Livin-negative patients [28,41]. In 2010, clinical significance of Livin expression in NHL was evaluated by Gao et al. They found that the expressions of Livin mRNA and protein were positively correlated with clinical stage of NHL, B symptom and some other clinical features [44]. On the other hand, some studies on Lung cancer [50,51], colon cancer [40], nasopharyngeal carcinoma [28] and metastatic melanoma have not shown any correlation between Livin over expression and any clinical outcome, despite the up-regulation of Livin in these malignancies. Considering all these controversial results about the prognostic importance of Livin expression in different malignancies, we decided to examine the expression of Livin in different stages of HL.

The present study is the first description of evaluation and clinical significance of Livin expression in HL. We evaluated the
Livin expression, not only in the bulk of infiltrating background cells but also in malignant ones and then compared Livin expression in affected lymph nodes to non-neoplastic lymphoid tissues. We found that differences in the expression of Livin in both neoplastic and nonneoplastic cell population is statistically significant in comparison with cell population in the control lymph nodes. Surprisingly, we found that the expression of Livin in malignant cells is higher than the nonneoplastic background cells.

One way to explain our finding is to consider the role of nuclear factor- kappa B (NF-k B) on up-regulation of IAPs [52]. It is known that TF (NF-kB) is activated in the reprogrammed HRS cells [2]. This activation can be effective in up-regulation of IAPs in the malignant cells compared to inflammatory background cells. More comprehensive molecular profiling studies are required to underpin this issue.

Our findings also revealed possibility of significant difference in Livin expression between the early stage cases and advanced-stage HL samples. Therefore, we suggest Livin as a potential prognostic factor for staging of HL as well as Livin targeting treatment in HL patients.

Different studies have indicated that histological type of HL is a prognostic indicator for HL survival, with NSCHL (the most frequent type) having a more favorable prognosis $[3,4]$. In the present study, LDCHL samples (the most aggressive form of HL [4] had the lowest M.R of Livin/GAPDH expression while the LRCHL cases (with a rich background of normal lymphocytes) had the highest M.R. of Livin/ GAPDH expression (Figure 6). This might be attributed to the low number of samples we studied. Hence, the authors recommend more studies with larger number of samples to evaluate the Livin expression in different types of HL.

Finally, it should be noted that a large body of evidence now supports the important function of Livin expression in the pathogenesis and progression of cancers. Livin has become an attractive target for cancer therapy by different strategies such as antisense oligonucleotides, protein function blocking and immunotherapy [28]. But, it is currently unknown whether pan-IAP inhibitors or a specific Livin inhibitors are the most useful therapeutically for the treatment of malignancies. Evaluation of all members of IAP family is therefore recommended to find a more vivid picture of their role in different stages of HL. We have extended our study to evaluate the NAIP expression profile in HL [49].

\section{Acknowledgments}

This research work was supported by Grant No. 187070 form the deputy for Research, Isfahan University of Medical Sciences, Isfahan, Iran. We would like to appreciate Dr. Ardeshir Talebi (Dept of Pathology, Isfahan University of Medical Sciences) for pathology diagnosis of cases, Dr. Mohamadreza Mohajeri and Ms. Sahar Mahmoodi for sample preparation and immunostanining in this project.

\section{References}

1. Yurchenko M, Sidorenko SP (2010) Hodgkin's lymphoma: the role of cell surface receptors in regulation of tumor cell fate. Exp Oncol 32: 214-223.

2. Küppers R (2009) Molecular biology of Hodgkin lymphoma. Hematology Am Soc Hematol Educ Program.

3. Mani H, Jaffe ES (2009) Hodgkin lymphoma: an update on its biology with new insights into classification. Clin Lymphoma Myeloma 9: 206-216.

4. Steidl C, Connors JM, Gascoyne RD (2011) Molecular pathogenesis of Hodgkin's lymphoma: increasing evidence of the importance of the microenvironment. J Clin Oncol 29: 1812-1826.

5. Küppers R, Hansmann ML (2005) The Hodgkin and Reed/Sternberg cell. Int J Biochem Cell Biol 37: 511-517.

6. Diehl V (2007) Hodgkin's disease--from pathology specimen to cure. N Engl J Med 357: 1968-1971. 
Citation: Ziaei A, Tanhaei AP, Mazrouei S, Kharaji M, Keyhanian K et al. (2015) Livin Expression by Semi-quantitative Immuno-flourecent Staining in Hodgkin Lymphoma: A Promising Marker or a Leading Role in Pathogenesis?. J Cytol Histol 6: 299. doi:10.4172/2157-7099.1000299

7. von Wasielewski R, Seth S, Franklin J, Fischer R, Hubner K, et al. (2000) Tissue eosinophilia correlates strongly with poor prognosis in nodular sclerosing Hodgkin's disease, allowing for known prognostic factors. Blood. 95: 1207-1213.

8. Persson-Dajotoy T, Andersson P, Bjartell A, Calafat J, Egesten A (2003) Expression and production of the CXC chemokine growth-related oncogenealpha by human eosinophils. J Immunol 170: 5309-5316.

9. Glimelius I, Rubin J, Rostgaard K, Amini RM, Simonsson M, et al. (2011) Predictors of histology, tissue eosinophilia and mast cell infiltration in Hodgkin's lymphoma--a population-based study. Eur J Haematol 87: 208-216.

10. Diehl V, Stein H, Hummel M, Zollinger R, Connors JM (2003) Hodgkin's lymphoma: biology and treatment strategies for primary, refractory, and relapsed disease. Hematology Am Soc Hematol Educ Program

11. Engert A, Plütschow A, Eich HT, Lohri A, Dörken B, et al. (2010) Reduced treatment intensity in patients with early-stage Hodgkin's lymphoma. $\mathrm{N}$ Engl J Med 363: 640-652.

12. Gandhi MK, Lambley E, Duraiswamy J, Dua U, Smith C, et al. (2006) Expression of LAG-3 by tumor-infiltrating lymphocytes is coincident with the suppression of latent membrane antigen-specific CD8+ T-cell function in Hodgkin lymphoma patients. Blood 108: 2280-2289.

13. Tzankov A, Dirnhofer S (2006) Pathobiology of classical Hodgkin lymphoma Pathobiology 73: 107-125.

14. Küppers R, Schwering I, Bräuninger A, Rajewsky K, Hansmann ML (2002) Biology of Hodgkin's lymphoma. Ann Oncol 13 Suppl 1: 11-18.

15. Aldinucci D, Gloghini A, Pinto A, De Filippi R, Carbone A (2010) The classical Hodgkin's lymphoma microenvironment and its role in promoting tumour growth and immune escape. J Pathol 221: 248-263.

16. Zelenetz AD, Abramson JS, Advani RH, Andreadis CB, Bartlett N, et al. (2011) Non-Hodgkin's Lymphomas. J Natl Compr Canc Netw 9: 484-560.

17. Jantas D, Lorenc-Koci E, Kubera M, Lason W (2011) Neuroprotective effects of MAPK/ERK1/2 and calpain inhibitors on lactacystin-induced cell damage in primary cortical neurons. Neurotoxicology 32: 845-856.

18. Davies AJ, Rosenwald A, Wright G, Lee A, Last KW, et al. (2007) Transformation of follicular lymphoma to diffuse large B-cell lymphoma proceeds by distinct oncogenic mechanisms. Br J Haematol 136: 286-293.

19. Schlette EJ, Medeiros LJ, Goy A, Lai R, Rassidakis GZ (2004) Survivin expression predicts poorer prognosis in anaplastic large-cell lymphoma. J Clin Oncol 22: 1682-1688.

20. de Graaf AO, van Krieken JH, Tönnissen E, Wissink W, van de Locht L, et al. (2005) Expression of C-IAP, C-IAP2 and SURVIVIN discriminates different types of lymphoid malignancies. Br J Haematol 130: 852-859.

21. Grzybowska-Izydorczyk O, Cebula B, Robak T, Smolewski P (2010) Expression and prognostic significance of the inhibitor of apoptosis protein (IAP) family and its antagonists in chronic lymphocytic leukaemia. Eur J Cancer 46: 800-810.

22. Grzybowska-Izydorczyk O, Smolewski $P$ (2008) [The role of the inhibitor of apoptosis protein (IAP) family in hematological malignancies]. Postepy Hig Med Dosw (Online) 62: 55-63.

23. Nachmias B, Ashhab Y, Ben-Yehuda D (2004) The inhibitor of apoptosis protein family (IAPs): an emerging therapeutic target in cancer. Semin Cancer Biol 14: 231-243.

24. Liston P, Fong WG, Korneluk RG (2003) The inhibitors of apoptosis: there is more to life than $\mathrm{Bcl} 2$. Oncogene 22: 8568-8580.

25. Kelly RJ, Lopez-Chavez A, Citrin D, Janik JE, Morris JC (2011) Impacting tumor cell-fate by targeting the inhibitor of apoptosis protein survivin. Mol Cancer 10 : 35.

26. Kren L, Brazdil J, Hermanova M, Goncharuk VN, Kallakury BV, et al. (2004) Prognostic significance of anti-apoptosis proteins survivin and bcl-2 in nonsmall cell lung carcinomas: a clinicopathologic study of 102 cases. App Immunohistochem Mol Morphol 12: 44-49.

27. Schimmer AD (2004) Inhibitor of apoptosis proteins: translating basic knowledge into clinical practice. Cancer Res 64: 7183-7190.

28. Wang L, Zhang Q, Liu B, Han M, Shan B (2008) Challenge and promise: roles for Livin in progression and therapy of cancer. Mol Cancer Ther 7: 3661-3669.
29. Sun C, Cai M, Meadows RP, Xu N, Gunasekera AH, et al. (2000) NMR structure and mutagenesis of the third Bir domain of the inhibitor of apoptosis protein XIAP. J Biol Chem 275: 33777-33781.

30. Chai J, Shiozaki E, Srinivasula SM, Wu Q, Datta P, et al. (2001) Structural basis of caspase-7 inhibition by XIAP. Cell 104: 769-780.

31. Ashhab Y, Alian A, Polliack A, Panet A, Ben Yehuda D (2001) Two splicing variants of a new inhibitor of apoptosis gene with different biological properties and tissue distribution pattern. FEBS Lett 495: 56-60.

32. Yan B (2011) Research progress on Livin protein: an inhibitor of apoptosis. Mol Cell Biochem 357: 39-45.

33. Kasof GM, Gomes BC (2001) Livin, a novel inhibitor of apoptosis protein family member. J Biol Chem 276: 3238-3246.

34. Ma L, Huang Y, Song Z, Feng S, Tian X, et al. (2006) Livin promotes Smac DIABLO degradation by ubiquitin-proteasome pathway. Cell Death Differ 13 2079-2088.

35. Sun C, Cai M, Gunasekera AH, Meadows RP, Wang H, et al. (1999) NMR structure and mutagenesis of the inhibitor-of-apoptosis protein XIAP. Nature 401: 818-822.

36. Vucic D, Franklin MC, Wallweber HJ, Das K, Eckelman BP, et al. (2005) Engineering ML-IAP to produce an extraordinarily potent caspase 9 inhibitor: implications for Smac-dependent anti-apoptotic activity of ML-IAP. Biochem $J$ 385: 11-20.

37. Ye L, Song X, Li S, Yang D, Zhang J, et al. (2011) Livin-Ît promotes cell proliferation by regulating $\mathrm{G} 1-\mathrm{S}$ cell cycle transition in prostate cancer. Prostate 71: $42-51$

38. Choi J, Hwang YK, Sung KW, Lee SH, Yoo KH, et al. (2007) Expression of Livin, an antiapoptotic protein, is an independent favorable prognostic factor in childhood acute lymphoblastic leukemia. Blood 109: 471-477.

39. Reed CJ (2000) Apoptosis and cancer: strategies for integrating programmed cell death. Semin Hematol 37: 9-16

40. Wang X, Xu J, Ju S, Ni H, Zhu J, et al. (2010) Livin gene plays a role in drug resistance of colon cancer cells. Clin Biochem 43: 655-660.

41. Gazzaniga P, Gradilone A, Giuliani L, Gandini O, Silvestri I, et al. (2003) Expression and prognostic significance of LIVIN, SURVIVIN and othe apoptosis-related genes in the progression of superficial bladder cancer. Ann Oncol 14: 85-90

42. Kim DK, Alvarado CS, Abramowsky CR, Gu L, Zhou M, et al. (2005) Expression of inhibitor-of-apoptosis protein (IAP) livin by neuroblastoma cells: correlation with prognostic factors and outcome. Pediatr Dev Pathol 8: 621-629.

43. Crnogorac-Jurcevic T, Efthimiou E, Nielsen T, Loader J, Terris B, et al. (2002) Expression profiling of microdissected pancreatic adenocarcinomas. Oncogene 21: $4587-4594$

44. Gao JM, Wang X, Liu XQ, Ge XL, Ding M, et al. (2010) [Clinical significance of Livin expression in non-Hodgkin's lymphoma]. Zhongguo Shi Yan Xue Ye Xue Za Zhi 18: 385-390.

45. Rosenberg SA, Boiron M, DeVita VT Jr, Johnson RE, Lee BJ, et al. (1971) Report of the Committee on Hodgkin's Disease Staging Procedures. Cancer Res 31: 1862-1863.

46. Lister TA, Crowther D, Sutcliffe SB, Glatstein E, Canellos GP, et al. (1989) Report of a committee convened to discuss the evaluation and staging of patients with Hodgkin's disease: Cotswolds meeting. J Clin Oncol 7: 16301636.

47. Salehi M, Barron M, Merry BJ, Goyns MH (1999) Fluorescence in situ hybridization analysis of the fos/jun ratio in the ageing brain. Mech Ageing Dev 107: 61-71.

48. Kabiri Z, Salehi M, Mokarian F, Mohajeri MR, Mahmoodi F, et al. (2009) Evaluation of $A R G$ protein expression in mature $B$ cell lymphomas compared to non-neoplastic reactive lymph node. Cell Immunol 259: 111-116.

49. Mazrouei S, Ziaei A, Tanhaee AP, Keyhanian K, Esmaeili M, et al. (2012) Apoptosis inhibition or inflammation: the role of NAIP protein expression in 
Citation: Ziaei A, Tanhaei AP, Mazrouei S, Kharaji M, Keyhanian K et al. (2015) Livin Expression by Semi-quantitative Immuno-flourecent Staining in Hodgkin Lymphoma: A Promising Marker or a Leading Role in Pathogenesis?. J Cytol Histol 6: 299. doi:10.4172/2157-7099.1000299

Page 7 of 7

Hodgkin and non-Hodgkin lymphomas compared to non-neoplastic lymph node. J Inflamm (Lond) 9: 4.

50. Yagihashi A, Asanuma K, Kobayashi D, Tsuji N, Shijubo Y, et al. (2005) Detection of autoantibodies to livin and survivin in Sera from lung cancer patients. Lung Cancer 48: 217-221.

51. Wang LN, Mou J, Zhang YB, Dong P, Diao X, et al. (2010) [Inhibitor of apoptosis in lung cancer Livin perioperative clinical research]. Xi Bao Yu Fen Zi Mian Yi Xue Za Zhi 26: 889-890.

52. Notarbartolo M, Poma P, Perri D, Dusonchet L, Cervello M, et al. (2005) Antitumor effects of curcumin, alone or in combination with cisplatin or doxorubicin, on human hepatic cancer cells. Analysis of their possible relationship to changes in NF-kB activation levels and in IAP gene expression. Cancer Lett 224: 53-65. 